\title{
Courage: Journey from comfort zone to camping in wild- A Narrative Approach
}

\author{
Mrs. Poorva Ranade \\ Dept.of Psychology, Jain University, India.
}

\begin{abstract}
When an individual confronts any challenging situation - physical, mental or emotional, courage quality of human strength is revealed. This study relates to the personal experience about camping in wilderness of Eagle Nest Sanctuary of Arunachala Pradesh in India. Both the nature camps were situated amidst dense forest, with conditions such as no power(electricity), freezing weather and water, long dark hours, no medical facility within reach, and canvas tents.Narrative Analysis has been used as a tool to give meaning to this unique individual experience of camping in the nature. Themes such as creativity, courage, resilience, happiness, confidence were emerged as a result of narrative inquiry. It can be concluded that imagery of an experience of confronting challenging situations in the past will be helpful in building self-confidence. For any individual to build and maintain relationships, out-bound activities provides an opportunity to understand group dynamics better. When any individual steps out of comfort zone, learning outcome helps him build confidence and resilience. Ultimately an individual has the freedom and choice to give meaning and context to understand courage.
\end{abstract}

Keywords: comfort zone, courage, human strength, narrative approach, resilience

\section{Introduction}

Objective: To understand human strength-courage by stepping out of comfort zone.

When an individual come across a situation, which is very challenging in any form could be physical, mental or emotional, courage -quality of human strength is revealed. There is underlying fear and anxiety about dealing with adverse situations. One of the questions asked was - What are the strengths associated with courage in positive psychology? According to Siegel (2014)[1] the virtue of courage is associated with strengths of will that help you accomplish goals in the face of fear and internal or external obstacles with components such as integrity, bravery, persistence and vitality.

These components can be briefly described ....

Integrity deals with ethical and moral values such as being truthful, honest, and sincere. Being open and frank and projecting your true self through your actions and feelings.

Bravery portrays belief in your value system and acting accordingly despite opposition. Confronting challenges - like physical mental, emotional, difficulties, threats, or pain.

Persistence: in spite of difficulties finishing what you have started wholeheartedly and with might.

Vitality: giving your one hundred percent focus to the work and with enthusiasm and energy.

Many times it so happens that we have the necessary skills to sail through the tough situation successfully. But these skills/ strengths are either not tapped or forgotten by the individual in the due course of time.

\section{Material and method}

\subsection{Narrative}

This narration relates to the personal experience of camping in wild in extreme conditions by a narrator. As a nature enthusiast and bird watcher, narrator, with her family had planned a trip to North-east of India- Arunachala Pradesh during 22nd Dec.13 till 1st of Jan 14.Out of total ten days, four days were spent at two camps-one is Lama camp and the other is Bompu camp. Both these camps are nestled right in the middle of Eagle-Nest wildlife Sanctuary, located at $2780 \mathrm{~m}$. above sea level, in the West Kameng District of Arunachala Pradesh (India)(Fig.1). Eagle-Nest wildlife Sanctuary is particularly famous for different, rare and endemic bird species- It is bird watchers' paradise. As a precautionary measure, we were advised to carry lots of woollens to protect us from the cold weather as both the places were situated amidst the mountains. The whole experience of camping in the wild was very intense and insightful for the narrator. And felt the need to share this camping journey and its outcome in a form of a narrative with all. 


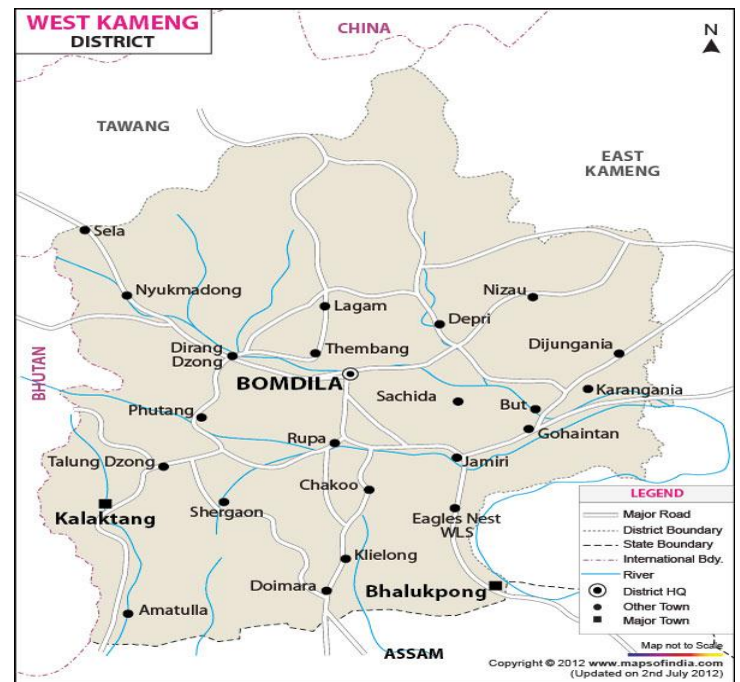

Map of West Kameng District, Arunachala, India.(figure.1)[2]

Situation at both - Lama and Bompu camps in a nutshell: - there was no power (electricity), weather and water was ice-cold, sun used to set by 5p.m.leaving long dark hours, no medical facility within reach, and canvas tents. Every day we had to trek nearly 3 to $4 \mathrm{kms}$ on foot through the jungles. Morning our day used to start by 5 a.m. and used to end by 10.00 in the night. Idea about extreme situations was given to us in advance. We were all ready with our binoculars, torches, woollens but actually being there and facing situations was totally different and difficult. After citing every bird there was a moment of an awe!!!. Vivid colours, crests, striations, conspicuous markings on their wings and tails. Their calls and flights feast for the eyes and ears.

Experience at Lama Camp.

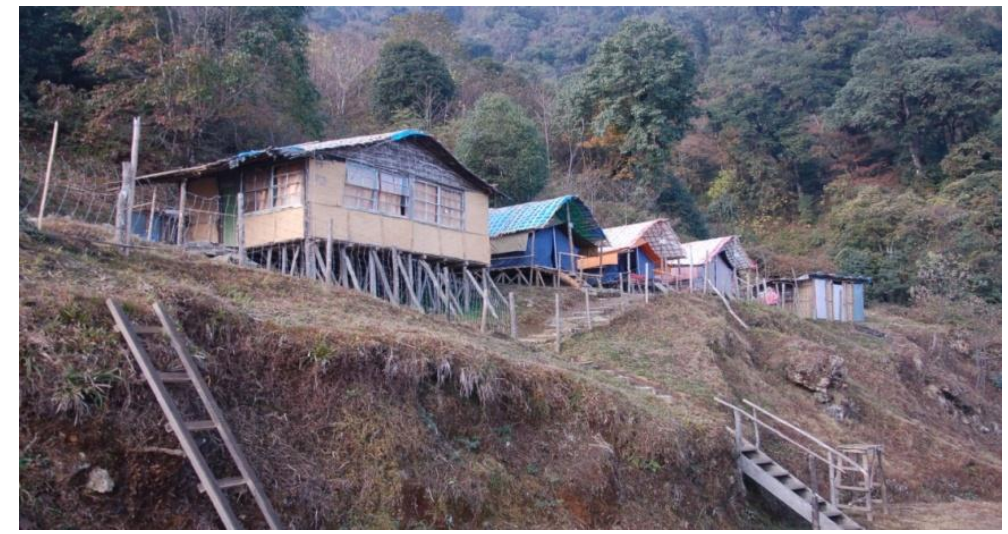

Lama camp site,(Figure.2)[3]

Lama Camp(Fig.2): Surrounded by mountains and valleys. Weather was extremely cold, near zero degrees centigrade. No one could afford to take out hands out of the gloves even for a wash. In the morning water in pipes were frozen. Even idea of a bath was beyond imagination. Using toilet paper made us understand hygiene at its best!!!. We could see traces of ice on ghat road on our early morning trek. Birds like Thrushes, Olive backed pipits; Bullfinches were chirping and busy munching berries and insects for their breakfast. We also had a royal breakfast amidst on the serpentine roads in mountains. In the afternoon, When went till eagle nest pass which is at $2780 \mathrm{mts}$ height above sea level we could not believe ourselves that bird life exists there!. There was heavy white and grey mist and clouds were moving rapidly. The atmosphere was very gloomy and scary. We were surprised to see the trails made by the elephants at such an elevation. Our guide explained that here elephants come to eat Bamboo. After spending 2 to 3 hours trekking all of us returned back to camp by 3.45 in the afternoon tired and exhausted. At 5 in the evening there was dark outside nothing could be seen. Then mandatory ritual was we all used to sit around fireplace and getting warmth and munching on hot snacks. Around 7.30 in the evening we used to list down all the birds we had sighted during the day referring the bird book. When we were returning to our tents after dinner, we saw literally a starry night above. It was just beyond description. One surely has to experience by himself. The best ever show of lighting seen so far. Chilled weather was restricting us viewing this sight for a long time. Outside temperature declined still further almost to near 
zero degrees. We all slipped into our canvas tents; to our amazements we found even beds were extremely cold. On that very moment of time one of the cooks came and gave us hot water bags to put them below our legs. Life is a struggle was a passing thought. After spending two nights at Lama we headed for Bompu camp which was on the little lower elevation!!!!!

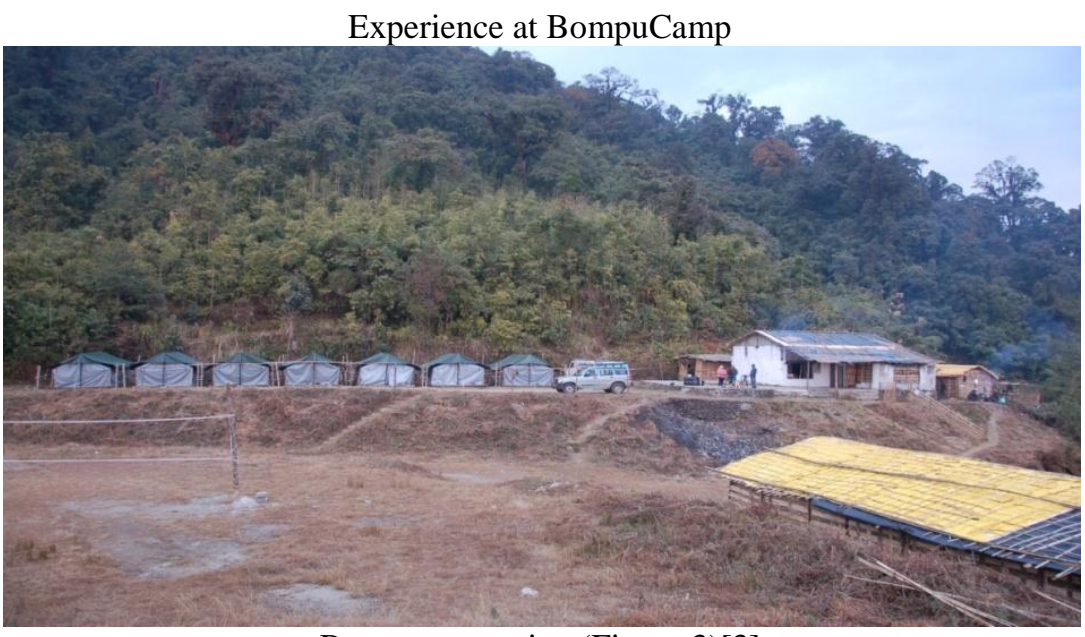

Bompu camp site, (Figure.3)[3]

When we reached at Bompu camp site (Fig.3) it was 4.30 p.m. and already started getting foggy and dark. At the camp cooks broke the news that there were wild elephants just down below the camp. Even they were discussing among themselves who will go where and secure themselves in case of elephant attack. They had lit fire and were burning wet bamboo. When wet bamboo is burnt, it makes periodic sounds which resembles to bursting of crackers. This information was addition to our knowledge bank. The whole drama went on for nearly an hour to chase elephants away. When we went back to our tents the very thought of elephant attack made us shiver and gave chills in the spine. Back up plans about saving ourselves??, were started churning in our brains. Everybody was getting creative at their best and suggesting novel ideas. At that time all of us were one. Ideas like one can cut the tent with a Swiss -knife and come out and run. Considering the size and the mood of the attacking elephant no plan was working out satisfactorily. We had to just be there and do best possible we can was the final outcome of brain storming. At the same time to add it to our knowledge guide mentioned about wild elephants, clouded leopards roaming freely. We could understand that we could do very little to safeguard ourselves. Finally we gave up on thinking. Whole through the night, mind and every cell in the body was on constant alert to the slightest movement and sound eagerly waiting for a morning.

Next day morning, when we went for birding, on the trail we could to see traces of elephant dung after every few meters away, sometimes fresh sometimes dried. After sighting birds like Minlas, Great Barbets, Cutias, for that moment we forgot we were in the wild and just concentrated on looking at bird, observing its peculiar characteristics. Throughout mind kept on wondering and waiting to see what is next? While trekking in the forest, since there was no forest ranger with a gun to accompany us, even a slightest of the movement and noise of leaves could make us alert and watchful. Further we went down to place named Sisni, where we sighted deep red colour bird called scarlet finch and saw plenty of birding activity. By evening we came back to our camp site. Dark nights kept us all the time in half sleep and half-awake situation eagerly waiting for the sun to rise. The most important thought kept on recurring was how people live here. Next day morning at 5.00 we packed up and headed for our next halt - place called Dirang.

2.2 Method

As Narrative analysis [4] captures both individual and context of the lived personal experiences (Czarniawska, (2004)) [5], researcher had chosen it as a tool for analysis. With the functional application of this qualitative analysis tool, narrator aimed at giving meaning to rich and lived experience.

\section{Results and Discussion}

Themes such as creativity, courage, resilience, happiness, confidence were emerged as a result of narrative inquiry.

Everybody agrees to the fact that cash is the most liquid asset which saves a person from financial problems. On the same lines, this personal experience helped in understanding the narrator that Courage is the most liquid asset within us. Stepping out of one's comfort zone helps to unravel this human strength and helps in improving quality of life. When one is aware about the risks involved in task, both mind and body coordinates with each other. One is prepared for confrontation with adverse situations by remaining alert. After 
watching the starry night narrator could not take eyes out of that miraculous sight. At that time realization occurred about the value of having all our five senses intact and working to its full potential. Respecting and taking care of physical and mental set up should be always on the priority, was very important lesson learnt in the practical setting.

When we observed life of people who were living there, they were laughing and seemed to be adapted well in those harsh conditions. Struggle of those people and their connect with environment was worth a salute. Our ideas about living life in comforts started to dwindle. At Bompu Camp, where elephants were roaming just below our camp site, it was very clearly understood that situation always cannot be under your control. It is better to leave it to the destiny and not think too much. Instead, confront it and give your best. Let the creativity flow towards working out solution and not getting stuck at any point of time.

While trekking in the forest for bird watching we had to go deep inside the forest. Everybody used to be vigilant and on guard. As there was no forest ranger our guide always insisted on sticking together as group and alarm in case of danger. Togetherness helped us in feeling secured and could enjoy each bird sighting. Group dynamics was easily understood and learnt without much ado.

Watching patterns and shades of green and brown colour spread across the mountain was feast for eyes. Sounds of wind and bird calls maintained perfect melody in the jungle. Scenery and patterns of nature created a sort of imagery which is very hard to forget.

Since most of birds are endemic to this sanctuary. There was always a moment of an awe!!! at the sighting of any bird. Vivid colours, crests, striations, conspicuous markings on their wings and tails were so amazing and were beyond imagination. Each creation of nature looked precise and perfect. Words failed to admire nature's beauty. All of us used to get so excited that sometimes we used to jump with happiness and joy forgetting everything else.

This whole experience of camping in the wild was an eye opener which changed narrator's overall perspective of looking at life.

\section{Conclusion}

In cases where one feels low or have low self-concept about oneself, imagery of an experience of confronting challenging situations in the past will be helpful in building their self-confidence and morale. In building relationships at workplace as well as within family leaving comfort zone will provide an opportunity to build resistance and resilience by challenging one's thought processes. In order to understand innate nature of this liquid asset- courage, one should be self-motivated. Ultimately an individual has the freedom to give meaning and context to understand courage. Out- bound learning activities will help people in exploring courage- as human strength within them.

\section{Acknowledgements}

I would sincerely like to thank my Phd guide Dr.Pooja Surana who motivated me to know and learn more about positive psychology. My husband Mr. Sunil and daughter Miss Shruti for their photography skills. My son, Master Shashank for moral support throughout. Guide Rohan and our Driver Binodji for this exclusive experience.

\section{References}

[1]. Siegel, R. http://www.sharecare.com/health/personality/what-strengths-courage-positive-psychology. Retrieved on 01/09/2014

[2]. Www.googlemaps.com

[3]. Ranade, S; Ranade, S. (2013): Images

[4]. Heikkinen, H. L. T. (2002). Whatever is narrative research? In R. Huttunen, H. L. T. International Journal of Qualitative Methods 5 (4) December 2006 http://www.ualberta.ca/ ijqm/ retrieved 01/11/14

[5]. Czarniawska, ? (2004) http://www.sagepub.com/upmdata/13421_Chapter4.pdf retrieved on/01/09/14 